\title{
Spatial and Long-Term Temporal Changes in Water Quality Dynamics of the Tonle Sap Ecosystem
}

\author{
Savoeurn Soum ${ }^{1,2,3, *(1)}$, Peng Bun Ngor ${ }^{1,4}\left(\mathbb{D}\right.$, Thomas E. Dilts ${ }^{1,5}$, Sapana Lohani ${ }^{1,5,6,7,8}$, Suzanne Kelson ${ }^{1}$, \\ Sarah E. Null ${ }^{1,7}{ }^{\circ}$, Flavia Tromboni $\left.{ }^{1,6}{ }^{(}\right)$, Zeb S. Hogan ${ }^{6}$, Bunyeth Chan ${ }^{1}\left(\mathbb{D}\right.$ and Sudeep Chandra ${ }^{1,6}$ \\ 1 Wonders of the Mekong Project, c/o Inland Fisheries Research and Development Institute, \\ Fisheries Administration, No. 186 Preah Norodom Blvd, Khan Chamkar Morn, \\ Phnom Penh 12300, Cambodia; pengbun.ngor@gmail.com (P.B.N.); tdilts@unr.edu (T.E.D.); \\ sapana.lohani@mso.umt.edu (S.L.); skelson@unr.edu (S.K.); sarah.null@usu.edu (S.E.N.); \\ ftromboni@unr.edu (F.T.); bunyethchan@gmail.com (B.C.); sudeep@unr.edu (S.C.) \\ 2 Department of Biology, Faculty of Science, Royal University of Phnom Penh, Russian Boulevard, \\ Phnom Penh 12000, Cambodia \\ 3 Graduate School, Chea Sim University of Kamchaymear, No. 157 Preah Norodom Blvd, Khan Chamkarmon, \\ Phnom Penh 12300, Cambodia \\ 4 Inland Fisheries Research and Development Institute, Fisheries Administration, No. 186 Preah Norodom \\ Blvd., P.O. Box 582, Phnom Penh 12300, Cambodia \\ 5 Department of Natural Resources and Environmental Science, University of Nevada, Reno, NV 89557, USA \\ 6 Department of Biology, Global Water Center, University of Nevada, 1664 N. Virginia Street, \\ Reno, NV 89557, USA; zebhogan@hotmail.com \\ 7 Department of Watershed Sciences, Utah State University, Logan, UT 84322, USA \\ 8 W.A. Franke College of Forestry and Conservation, University of Montana, Missoula, MT 59812, USA \\ * Correspondence: sormsavoeurn168@gmail.com
}

Citation: Soum, S.; Ngor, P.B.; Dilts, T.E.; Lohani, S.; Kelson, S.; Null, S.E.; Tromboni, F.; Hogan, Z.S.; Chan, B.; Chandra, S. Spatial and Long-Term Temporal Changes in Water Quality Dynamics of the Tonle Sap Ecosystem. Water 2021, 13, 2059. https: / / doi.org/10.3390/w13152059

Academic Editor: Xing Fang

Received: 7 May 2021

Accepted: 16 July 2021

Published: 29 July 2021

Publisher's Note: MDPI stays neutral with regard to jurisdictional claims in published maps and institutional affiliations.

Copyright: (c) 2021 by the authors. Licensee MDPI, Basel, Switzerland. This article is an open access article distributed under the terms and conditions of the Creative Commons Attribution (CC BY) license (https:/ / creativecommons.org/licenses/by/ $4.0 /)$.

\begin{abstract}
Tonle Sap lake-river floodplain ecosystem (TSE) is one of the world's most productive freshwater systems. Changes in hydrology, climate, population density, and land use influence water quality in this system. We investigated long term water quality dynamics (22 years) in space and time and identified potential changes in nutrient limitation based on nutrient ratios of inorganic nitrogen and phosphorus. Water quality was assessed at five sites highlighting the dynamics in wet and dry seasons. Predictors of water quality included watershed land use, climate, population, and water level. Most water quality parameters varied across TSE, except $\mathrm{pH}$ and nitrate that remained constant at all sites. In the last decade, there is a change in the chemical nutrient ratio suggesting that nitrogen may be the primary limiting nutrient across the system. Water quality was strongly affected by development in the watershed i.e., flooded forest loss, climatic variation, population growth, and change in water level. Seasonal variations of water quality constituents were driven by precipitation and hydrology, notably the Mekong's distinct seasonal flood pulse.
\end{abstract}

Keywords: Mekong River Basin; Tonle Sap Lake; Tonle Sap River; hydroclimate; tropical lake; Cambodia

\section{Introduction}

Understanding water quality is key to understanding the health of an ecosystem [1]. Alterations to river hydrology, climate change, and nutrient loading due to anthropogenic pressure leads to the degradation of water quality and a reduction of biodiversity, fish survival, and fish growth [2-4]. The Mekong River is one of the world's largest tropical rivers, originating in China's Tibetan Plateau, and flows to the South China Sea [5]. While the river has been an important part of culture and society for thousands of years, in the past half-century, there have been substantial alterations to the Mekong River and its watershed including hydroclimate alterations, eutrophication, and deforestation $[2,6,7]$.

Tonle Sap Lake (TSL) is in the Lower Mekong watershed and is one of the most productive freshwater fisheries in the world [8]. TSL has been recognized as a UNESCO 
Biosphere Reserve due to its rich biodiversity and functional importance [9]. Together, the lake, river, and tributaries form a large and connected floodplain system called Tonle Sap Ecosystem (TSE) [10]. This ecosystem is tightly linked to water levels of the Mekong River. Flooded forest and floodplains are the primary sources of sediments and nutrients delivered to TSL [11] leading to extraordinary fish production [12]. The Tonle Sap River (TSR) has bi-directional flow depending on the season. In the wet season (June to November), water flows from the Mekong River to TSL, whereas TSL drains into the TSR into the Mekong River during the dry season (December to May) [13]. The TSE supports the economic wellbeing of Cambodia, providing food and especially protein to support human health [10]. The fishes returning from the lake into the TSR provide $70 \%$ of Cambodia's total inland fish catch, or 767,000 tonnes annually [14]. This is $80 \%$ of the protein for the people in Cambodia [15]. Moreover, the TSE supports both dry and wet season rice agricultural production [16].

The TSE is increasingly stressed by environmental pressures, such as changes to the watershed and hydrology of the Mekong River, which increase water pollution [2,5,17]. Recent studies have also highlighted changes in flooding regimes, alterations to floodplain habitats [18-20], and changes in river flows [21]. Dams built on the Mekong River mainstem and its tributaries have reduce streamflow and sediments flowing to TSL [11,22-24]. Also, flooded forest loss in the TSE watershed, increasing agriculture runoff and climate change are causing physical and chemical changes and water quality problems in TSL $[16,25]$. The flooded forest in the TSE has a constant annual loss rate of $1.2 \%$ for the last 25 years (from 1993 to 2017) [26]. Watershed characteristics of the TSE such as forest cover, climate, and agriculture influence lake characteristics (e.g., lake temperature) in the southern part of TSL [27]. The northern part of TSL receives higher nutrient concentrations due to human activities and development [2].

In general, few studies on long-term water quality dynamics exist for tropical lakes and rivers. Studies from TSL are no exception despite its ecological and socio-economic importance. The objectives of this study are to: (i) quantify the long-term spatial and temporal patterns of water quality constituents (i.e., TSS, $\mathrm{TP}_{1} \mathrm{NO}_{3-}, \mathrm{NH}_{4}{ }^{+}, \mathrm{DO}, \mathrm{pH}$, water temperature, and dissolved inorganic nitrogen to total phosphorus ratio) in the TSE, and (ii) determine the effects of flow, climatic variables, land use types, and population density on water quality constituents. Quantifying the spatiotemporal variability and mechanisms regulating water quality patterns should assist Cambodian governmental institutions in developing policies to protect the productive fishery and livelihoods supported by the Lower Mekong Basin (LMB). To our knowledge, this is the first study of this kind analyzing high-resolution and long-term time-series data for a large tropical lake.

\section{Materials and Methods}

\subsection{Study Area}

We evaluated long-term, water quality trends from five river and lake sampling sites located in the TSE, situated from the central to northwestern portion of Cambodia (Figure 1). Prek Kdam (PK) is located in the TSR in Kandal Province. Kampong Chhnang $(\mathrm{KC})$ is a transition zone that connects the TSR to TSL [8]. Kampong Luong (KL) is located in the middle of TSL in Pursat Province [8] and the area is likely polluted by domestic wastes [28] particularly from the relatively crowded floating villages. Situated toward the north of the lake, Back Prea (BP) is at the drainage of Sangke River during the flooding period, and has extensive agricultural lands, swamps, floating vegetation, flooded plains, and grasslands. This site may be affected by pollution from agricultural wastes, urban waste from the town Battambong town, gold mining, and deforestation [8,28]. Similarly, Phnom Krom (PR) is at the mouth of Siem Reap River, a TSL tributary which flows through the town of Siem Reap. This site is influenced by upland agriculture practices and domestic waste that flows directly from Siem Reap River [28] and the floating villages. 


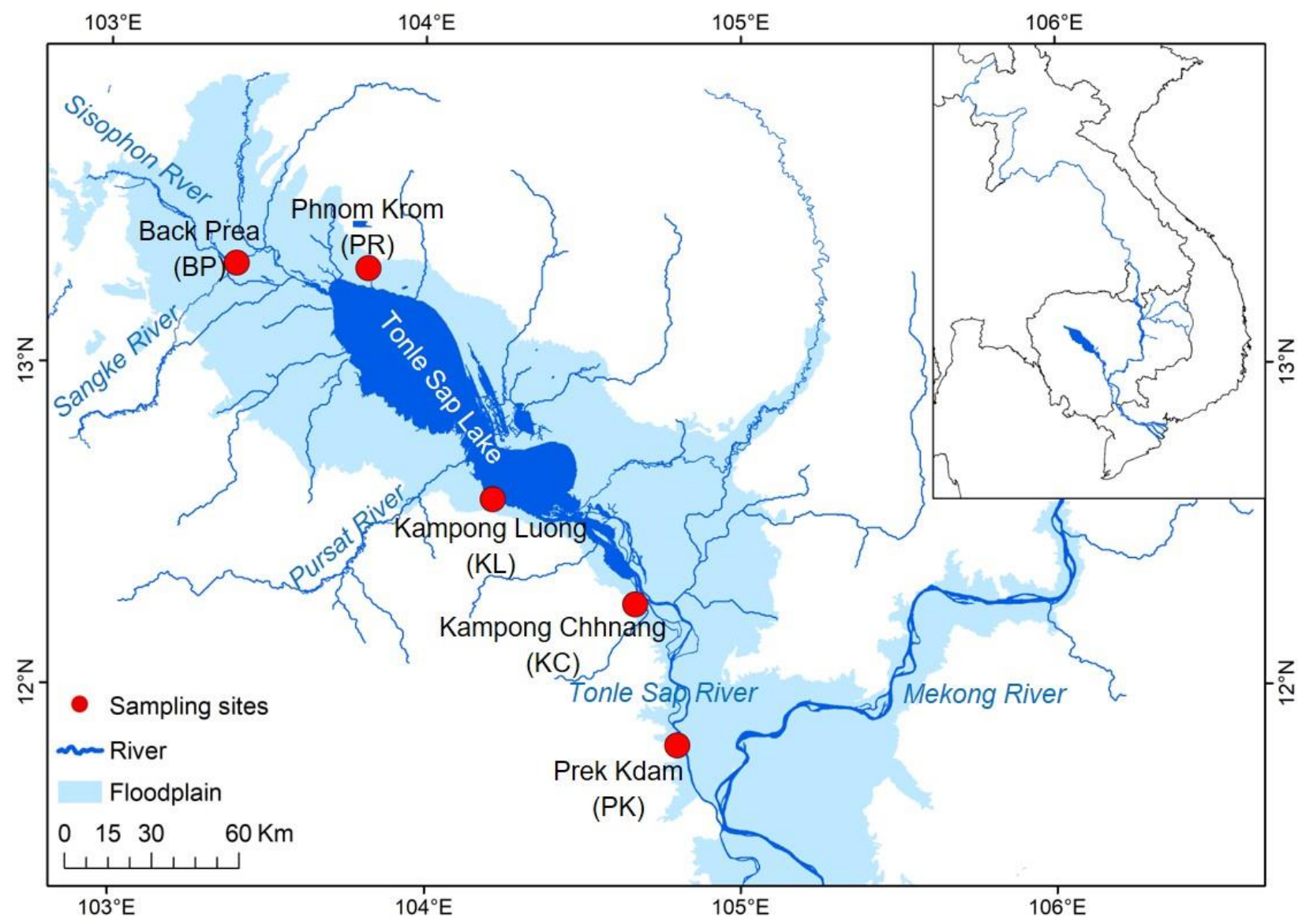

Figure 1. Sampling sites in the Tonle Sap Ecosystem.

The TSE catchment covers an area of approximately $85,790 \mathrm{~km}^{2}$ [13]. About $53.5 \%$ of inflow is from the Mekong River via the TSR, $12.5 \%$ is from precipitation, and $34 \%$ is from other tributaries [29]. Lake size and ecosystem dynamics are regulated by the flow pulse from the Mekong River and the contribution of water from tributary inflows that are driven by the tropical monsoon during the wet season [29]. The variation in water level in the Mekong River between seasons creates the two water flow regimes in the TSE. The maximum water level in TSL rise to nearly $10 \mathrm{~m}$ in wet season and the minimum water level decreases to less than $1 \mathrm{~m}$ in dry season [30]. Changes in water level between seasons change lake surface area and volume. The lake surface area ranges from $3500 \mathrm{~km}^{2}$ in the dry season to $14,500 \mathrm{~km}^{2}$ in the flooded season, while the water volume ranges from $1-2 \mathrm{~km}^{3}$ in the dry season to $50-80 \mathrm{~km}^{3}$ during the flooding season [30]. The floodplain of TSL watershed is dominated by rice fields and forests extending 20 to $40 \mathrm{~km}$ from the lake's edge [5].

\subsection{Sample Collection and Laboratory Techniques}

The physicochemical and water level data used in this study were obtained from the Water Quality Monitoring Network of the Mekong River Commission (MRC). The MRC in partnership with its member countries regularly monitors water quality on 48 stations in the LMB [31] and we analyzed the data from the five sites in the TSE, Cambodia (Figure 1). Three sites, PK, KC, and KL, were monitored from 1996 to 2017 while BP and PR were monitored from 2005 to 2017 . Water samples were collected from $30-50 \mathrm{~cm}$ below the water surface between the 13th and 18th day of each month [32].

Water sampling, preservation techniques, and chemical analysis protocols followed the methods outlined in The 20th edition of the Standard Methods for the Examination of Water and Wastewater [33] or the national standards complying with the requirements of method validation of ISO/IEC 17025-2005 (Table 1) [34]. In situ water quality measure- 
ments included water temperature $\left(\mathrm{wtem},{ }^{\circ} \mathrm{C}\right), \mathrm{pH}$, and dissolved oxygen $(\mathrm{DO}, \mathrm{mg} / \mathrm{L})$ which were measured using calibrated water quality probes. Grab samples of water were preserved in the field and brought to the laboratory at the Ministry of Water Resources and Meteorology in Phnom Penh to analyze ammonium, dissolved inorganic nitrogen, and total phosphorus [28]. Total suspended solids (TSS) were measured using a $0.45 \mu \mathrm{m}$ pore size glass fiber filter following the 2540-D-TSS-SM standard method (Table 1). Dissolved inorganic nitrogen (combined nitrate- $\mathrm{NO}_{3}{ }^{-}$and nitrite- $\mathrm{NO}_{2}$ ), hereafter referred to as ${ }^{\prime} \mathrm{NO}_{3}{ }^{-}$". Ammonium $\left(\mathrm{NH}_{4}{ }^{+}\right)$concentrations were measured following the 4500- $\mathrm{NH}_{4}{ }^{+}-\mathrm{SM}$ method with the minimum detection of $0.002 \mathrm{mg} / \mathrm{L}$ (Table 1). Total phosphorus (TP) concentration was measured by the stannous chloride method $(4500 \mathrm{SM})$ with the minimum detection of $0.003 \mathrm{mg} / \mathrm{L}$ (Table 1).

Table 1. List of the water quality methods used for each nutrient and total suspended solids.

\begin{tabular}{cccccc}
\hline Parameters & Abbreviation & Units & Methods & Filter & Detection Limit \\
\hline Total Nitrate and Nitrite & $\mathrm{NO}_{3}{ }^{-}$ & $\mathrm{mg} / \mathrm{L}$ & $4500-\mathrm{NO}_{3-2} / \mathrm{SM}$ & $0.45 \mu \mathrm{m}$ & $0.001 \mathrm{mg} / \mathrm{L}$ \\
\hline Total Phosphorus & $\mathrm{TP}$ & $\mathrm{mg} / \mathrm{L}$ & $4500-\mathrm{P} / \mathrm{SM}$ & $0.45 \mu \mathrm{m}$ & $0.003 \mathrm{mg} / \mathrm{L}$ \\
\hline Ammonium & $\mathrm{NH}_{4}{ }^{+}$ & $\mathrm{mg} / \mathrm{L}$ & $4500-\mathrm{NH}_{4}{ }^{+} / \mathrm{SM}$ & - & $0.002 \mathrm{mg} / \mathrm{L}$ \\
\hline Total Suspended Solids & $\mathrm{TSS}$ & $\mathrm{mg} / \mathrm{L}$ & $2540-\mathrm{D}-\mathrm{TSS}-\mathrm{SM}$ & $0.45 \mu \mathrm{m}$ & - \\
\hline
\end{tabular}

\subsection{Watershed Land-Use Estimations and Climate Data}

We delineated watershed area for each of the five study sites (Figure 1) using a 90-m resolution digital elevation model (DEM) [35]. We filled pits, calculated flow direction within an eight-cell neighborhood, and calculated flow accumulation to estimate watershed delineation [36]. Due to the low-angle topography of the Tonle Sap Basin and the coarse resolution of the 90-m DEM, the location of the study sites did not exactly match the DEM used to delineate the watersheds. To solve this issue, the location for each of the five site locations was manually moved to the nearest cell with a high flow accumulation (i.e., rivers).

In each of the five watersheds, we calculated the proportion of five land cover categories and population density at an annual resolution from 2000 to 2017. Total forest cover and flooded forest cover were from [26] which were smoothed in order to ensure realistic changes from one year to the next. The remaining land cover types were downloaded from the Regional Land Cover Monitoring System website [37] and included the proportion of rice, plantations (mostly rubber, cassava, and mangoes), and all other crop types. Fully urbanized land cover types were rare in this study area. Therefore, we used the Gridded Population of the World dataset version 4 [38] which provided gridded population estimates at $1 \mathrm{~km}$ resolution for five-year increments $(2000,2005,2010,2015$, and 2020). For the intervening years, we estimated the population by linearly interpolating between the five-year start and endpoints. The gridded population data was mapped as population count in $1 \mathrm{~km}$ grid cells.

Monthly mean precipitation and air temperature were downloaded from the Centre for Environmental Data Analysis [37,38] which is available at [39] using ncdf4 and raster packages in $R$ program to gather and synthesize the data $[40,41]$.

\subsection{Data Preparation}

Linear interpolation was used to estimate the missing values within our time-series data [42]. Missing values of daily water level data $(\sim 1.04 \%)$ in KL between January and March 1996 and April 1998 were filled by using a linear regression $\left(R^{2}=0.87\right)$ between the water level in PK and the water level in KL from April 1996 to December 2019. Next, we computed maximum monthly water level data from the daily data at both sites, KL and PK. As water level data from TSL were available only from KL, these data were also used as predictors for water quality parameters at other lake's sites (BP and PR). For the same 
reason, water levels in PK were used as predictors for water quality parameter analyses at river sites $\mathrm{PK}$ and $\mathrm{KC}$.

Since water quality data were not available for all years before 2005, we used data from 2005 to 2017 to compare water quality parameters among sites as well as between wet and dry season. However, to highlight temporal change and to evaluate the overall trend within a site, we used all data available at each site, which included data from 1996 to 2017 for KC, PK, and KL and from 2005 to 2017 for BP and PR.

Then, we studied the relationship between water quality parameters and drivers. Water quality parameters, precipitation and air temperature had a monthly; water levels had a daily timestep, and watershed land use was the annual proportion of land cover type. We used average wet and dry season data of monthly water quality parameters, air temperature, precipitation, monthly maximum water levels (Max. WL), and annual watershed land use data to study relationship between each water quality parameter and predictors in the wet and dry season in each site. After that, we averaged annual data of all predictors and water quality parameters to study their relationship overtime. We defined the wet season (June-November) and dry (December-May) seasons, based on 9-year mean daily water levels of the Mekong River when entering Cambodia in Stung Treng Province [43].

\subsection{Statistical Analyses and Data Presentation}

Water quality parameters at each site were described by descriptive statistics including mean, maximum, minimum, median, standard error, and standard deviation from 2005 to 2017. In aquatic systems, the dominant forms of inorganic nitrogen associated with nutrients enrichment include $\mathrm{NH}_{4}{ }^{+}$and $\mathrm{NO}_{3}{ }^{-}$; these chemical species are commonly measured to when trying to understand pollution [44]. TP is commonly measured in water since it includes orthophosphate, an inorganic phosphorus form, and in particulate matter which supply or uptake of inorganic phosphorus within water [45]. Moreover, DIN:TP can predict nutrient limitation on phytoplankton growth with $84 \%$ accuracy and applies to a variety of lake conditions and types [45]. Unfortunately, the long-term data collections used here do not include analysis of dissolved inorganic phosphorus including orthophosphate. As a result, we estimate the potential nutrient limitation of algal growth over time using chemical conditions of DIN:TP and estimated deviations from the Redfield's ratio (by weight) of 7.2. The DIN:TP ratio values above 7.2 suggest the potential for P-limitation, whereas values below this threshold (by weight) indicates N-limitation. We recognize there can be variation in the threshold ratio used to estimate nutrient limitation. Reasons for variation in this threshold includes the algal physiological condition, species community composition, and the chemical composition of constituents in the water. Thus, we view these estimations as a first cut at estimating nutrient limitation with subsequent research needed to quantify algal nutrient limitation in the TSE.

Differences in each water quality parameter (i.e., TSS, TP, $\mathrm{NO}_{3}{ }^{-}, \mathrm{NH}_{4}{ }^{+}, \mathrm{DIN}$ :TP ratio, $\mathrm{DO}, \mathrm{pH}$, and wtem) among sites were investigated using a non-parametric multiple comparison test after Kruskal Wallis test, using kruskalmc() function of "pgirmess" package. This method is useful to indicate which groups are different in multiple comparisons, using adjusted pairwise comparisons [46]. Then, the nonparametric Mann-Whitney test (MWT) for non-paired samples (using wilcox.test() function) was used to reveal the significant difference between dry and wet seasons within each site for water parameters (TSS, TP, $\mathrm{NO}_{3}{ }^{-}, \mathrm{NH}_{4}{ }^{+}, \mathrm{DIN}$ :TP ratio, and wtem for all sites, DO in $\mathrm{BP}$, and $\mathrm{pH}$ in PK, KL, and PR). $\mathrm{DO}$ in $\mathrm{PK}, \mathrm{KC}, \mathrm{KL}, \mathrm{PR}$, and $\mathrm{pH}$ in $\mathrm{KC}$ and $\mathrm{BP}$ were tested for significant difference between wet and dry seasons by using the paired t-test (PTT) because data for those parameters were normally distributed. Box and whisker plots were used to visualize patterns in water quality parameters among sites and between wet and dry season using the "ggplot2" package [47].

To address overall long-term trends in the parameters selected, we performed a seasonal and trend decomposition analysis using a loess algorithm for water quality param- 
eters (TP, $\mathrm{NO}_{3}{ }^{-}, \mathrm{NH}_{4}{ }^{+}, \mathrm{TSS}, \mathrm{DO}, \mathrm{pH}$, and wtem). The seasonal and trend decomposition loess algorithm was conducted by applying loess smoother, which allows fast computation for long time-series data and seasonal smoothing, and is robust in the presence of missing values and outliers [48]. This model was performed based on the "periodic" method using the $s t l$ () function of the "stats" package.

Following the time series decomposition analysis, the nonparametric seasonal MannKendall trend test (SMK) was applied to detect the long-term monotonic trend in the monthly data of the study water quality parameters when seasonality is accounted [49,50]. The null hypothesis $\left(\mathrm{H}_{0}\right)$ was that no monotonic trends in time series data existed due to seasonality [50,51]. SMK can carry all robust data, missing values, and skewness [52]. SMK also provides the significant and trend direction by providing a positive and negative z-value indicating an upward and downward trend, respectively. More information about SMK is in [50]. The model was performed using the smk.test() function of the "trend" package [53].

Finally, multiple linear regression models (MLR) were applied to determine the influence of predictors on water quality parameters in each site. In the model, response parameters were TSS, $\mathrm{DO}, \mathrm{pH}, \mathrm{NO}_{3}{ }^{-}, \mathrm{NH}_{4}{ }^{+}, \mathrm{TP}$, wtem, and DIN:TP while predictors were Max. WL, watershed land use, population density, air temperature, and precipitation. Before building the model, the dependent and independent parameters were log-transformed to reduce the effects of outliers on the model performance. Then, a backward variable selection approach based on Akaike information criterion was applied to remove unimportant parameters or retain important parameters using the "MASS" package [54].

The relative effect of each predictor on water quality parameters was assessed using the multiple linear regression standardized coefficients. The performance of the model was evaluated using the coefficient of determination (multiple R-squared). All data and statistical analyses were performed in the $R$ language program v.4.0.5 for Windows [55].

\section{Results}

\subsection{Spatial Variation in Water Quality Parameter}

We found median TSS, TP, and $\mathrm{NH}_{4}{ }^{+}$concentration was highest in PR followed by $\mathrm{BP}, \mathrm{KL}, \mathrm{KC}$, and PK (Figure 2). Median TSS was significantly different between PR and the other sites. For TP, the significant difference was found between PK, KC, and PR. $\mathrm{NH}_{4}{ }^{+}$tended to be higher north of TSL than in the south (except between PR and KL). Surprisingly, there was high variation in DO among the northern sites, with the lowest DO indicated in BP (median: $5.5 \pm 0.17 \mathrm{mg} / \mathrm{L}$ ) and the highest in PR (median: $6.6 \pm 0.11 \mathrm{mg} / \mathrm{L}$ ). The coolest water temperature in the TSE was in BP (median: $29.5 \pm 0.14^{\circ} \mathrm{C}$ ) while the warmest water temperature was in $\mathrm{KL}$ (median: $30.4 \pm 0.14^{\circ} \mathrm{C}$ ). Water temperature was similar among sites in the southern portion of TSL, and similarly tended to be higher in the northern sites. The DIN:TP ratio was under 7.2 by weight with significant variability among sites. The highest median of DIN:TP ratio was at $\mathrm{BP}(2.0 \pm 0.97)$ and the lowest value was at $\mathrm{PR}(1.4 \pm 1.37) . \mathrm{NO}_{3}{ }^{-}$and $\mathrm{pH}$ were not significantly different for any pairwise comparisons between sites. 

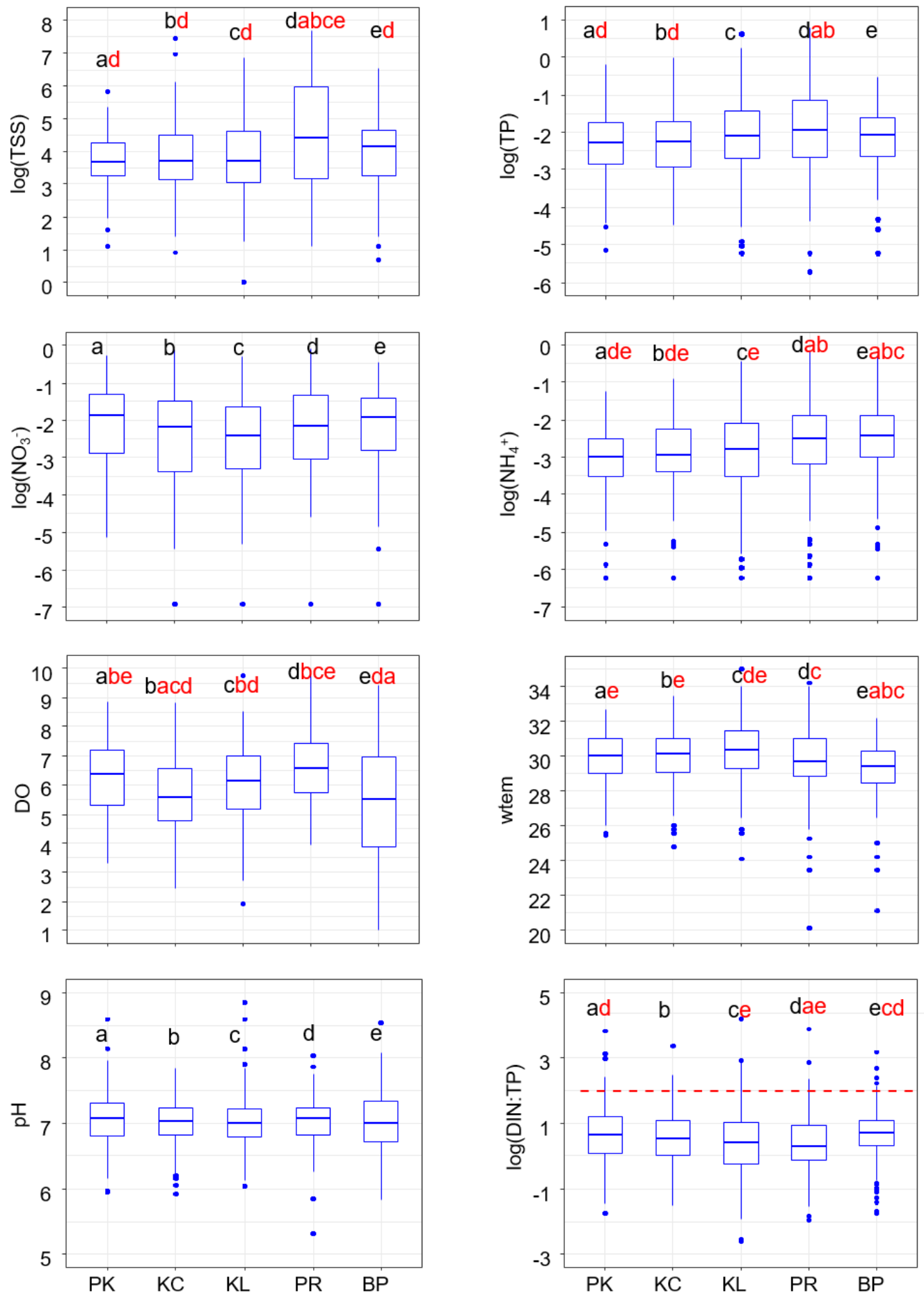

Figure 2. Variability of water quality parameters across the Tonle Sap Ecosystem and the results of the multiple comparison test after Kruskal Wallis test. The red dashed line indicates the DIN:TP ratio value at 7.2. Values above and below 7.2 indicate P-limited and N-limited, respectively. Abbreviations are as follows: PK: Prek Kdam; KC: Kampong Chhnang; KL: Kampong Luong; BP: Back Prea; PR: Phnom Krom. The label “a, b, c, d, and e” in black refer to PK, KC, KL, PR, and BP, respectively. Red letters refer to sites that were significantly different $(p<0.05)$. The location of each site is shown in Figure 1.

\subsection{Temporal Trends in Water Quality Parameter}

\subsubsection{Trend Analyses of Water Quality Parameters}

Most water quality parameters significantly increased over time except $\mathrm{NO}_{3}{ }^{-}$(Table 2). TSS and TP time series increased significantly at all sites in the south of the lake (PK and $\mathrm{KC}$ ), except for the northern sites (BP and PR) where no significant change in TP values 
was detected. $\mathrm{NO}_{3}{ }^{-}$trends were significantly downward at river sites in the south but increased trend in $\mathrm{BP}$, the northern part of the lake. $\mathrm{NH}_{4}{ }^{+}$trend was significantly upward at river sites in the southern part of TSL. DO trend increased significantly at rivers sites in the south and in the northern portion (BP) of the lake. $\mathrm{pH}$ trends increased significantly at the south and northern section (BP) of the lake. Last but definitely not least, water temperature trend increased significantly in the northern part (BP and PR) of the lake over the study period. Detailed results regarding the time-series decomposition analysis are given in the Supplementary Materials Table S2.

Table 2. Seasonal Mann-Kendall analysis on monthly water quality parameter time series.

\begin{tabular}{cccccccc}
\hline \multirow{8}{*}{ Site } & \multicolumn{7}{c}{ Parameters } \\
\cline { 2 - 8 } & TSS & TP & $\mathbf{N O}_{3}{ }^{-}$ & $\mathbf{N H}_{4}{ }^{+}$ & DO & pH & wtem \\
\hline PK & $+4.57^{* * *}$ & $+9.74^{* * *}$ & $-3.99^{* * *}$ & $+4.03^{* * *}$ & $+6.57 * *$ & +1.95 & -0.84 \\
$\mathrm{KC}$ & $+7.79^{* * *}$ & $+10.35^{* * *}$ & $-3.70^{* * *}$ & $+3.77^{* * *}$ & $+2.65^{*}$ & $+2.00^{*}$ & +0.86 \\
$\mathrm{KL}$ & $+5.52^{* * *}$ & $+8.65^{* * *}$ & -0.75 & +1.37 & +0.49 & $+2.35^{*}$ & +0.82 \\
$\mathrm{PR}$ & $+3.44^{* * *}$ & -0.35 & -0.53 & +0.81 & +0.28 & $+1.46^{*}$ & $+2.84^{* *}$ \\
$\mathrm{BP}$ & +0.16 & +1.22 & $+3.15^{*}$ & +0.37 & $+6.62^{* * *}$ & $+4.37^{* * *}$ & $+2.25^{*}$ \\
\hline
\end{tabular}

The values are the standardized z-statistic with plus " + " and minus " - " signs indicate the positive and negative long-term trend in the water quality constituents in each study site. The $p$-value denotes the significance level of the detected trend. The $p$-value follows ${ }^{*} p$-value $\leq 0.05,{ }^{* *} p$-value $\leq 0.01$, and ${ }^{* * *} p$-value $\leq 0.001$.

\subsubsection{Temporal Variation of DIN:TP Ratio by Wet and Dry Season}

Long-term DIN:TP ratio by weighted mass illustrated that algal production in southern sites may have changed from P-limited to N-limited while sites in the north were N-limited over time (Figure 3). The sites in the south of the lake such as PK, KC, and KL dropped below 7.2 between 2003 to 2017, suggesting the potential changes in nutrient limitation of algal growth from phosphorus to nitrogen during the study period from 1996 to 2017. Sites in the north (BP and PR) were always under the ratio of 7.2, suggesting N-limitation during the study period from 2005 to 2017.

\subsection{Seasonal Patterns of Water Quality}

The seasonal difference for each water quality parameter is demonstrated in Figure 4. Wet season TSS was significantly lower than that of the dry season in most study sites (KC, $\mathrm{KL}$, and BP) except PR. TP values in the wet season were significantly lower than those in the dry season, particularly in $\mathrm{KC}$ and $\mathrm{KL}$. No significant seasonal difference in $\mathrm{NO}_{3}{ }^{-}$was indicated, except at $\mathrm{BP}$ when dry season, $\mathrm{NO}_{3}{ }^{-}$was higher than that of the wet season. Wet season DO was significantly higher than dry season $\mathrm{DO}$ at $\mathrm{KC}, \mathrm{KL}$, and $\mathrm{PR} . \mathrm{NH}_{4}{ }^{+}$ and $\mathrm{pH}$ during the dry season were significantly higher than the wet season at all sites. However, there were no significant differences in water temperature between seasons at any sites. Lastly, the DIN:TP ratio in the dry season was significantly higher than the wet season at PK and BP only. 

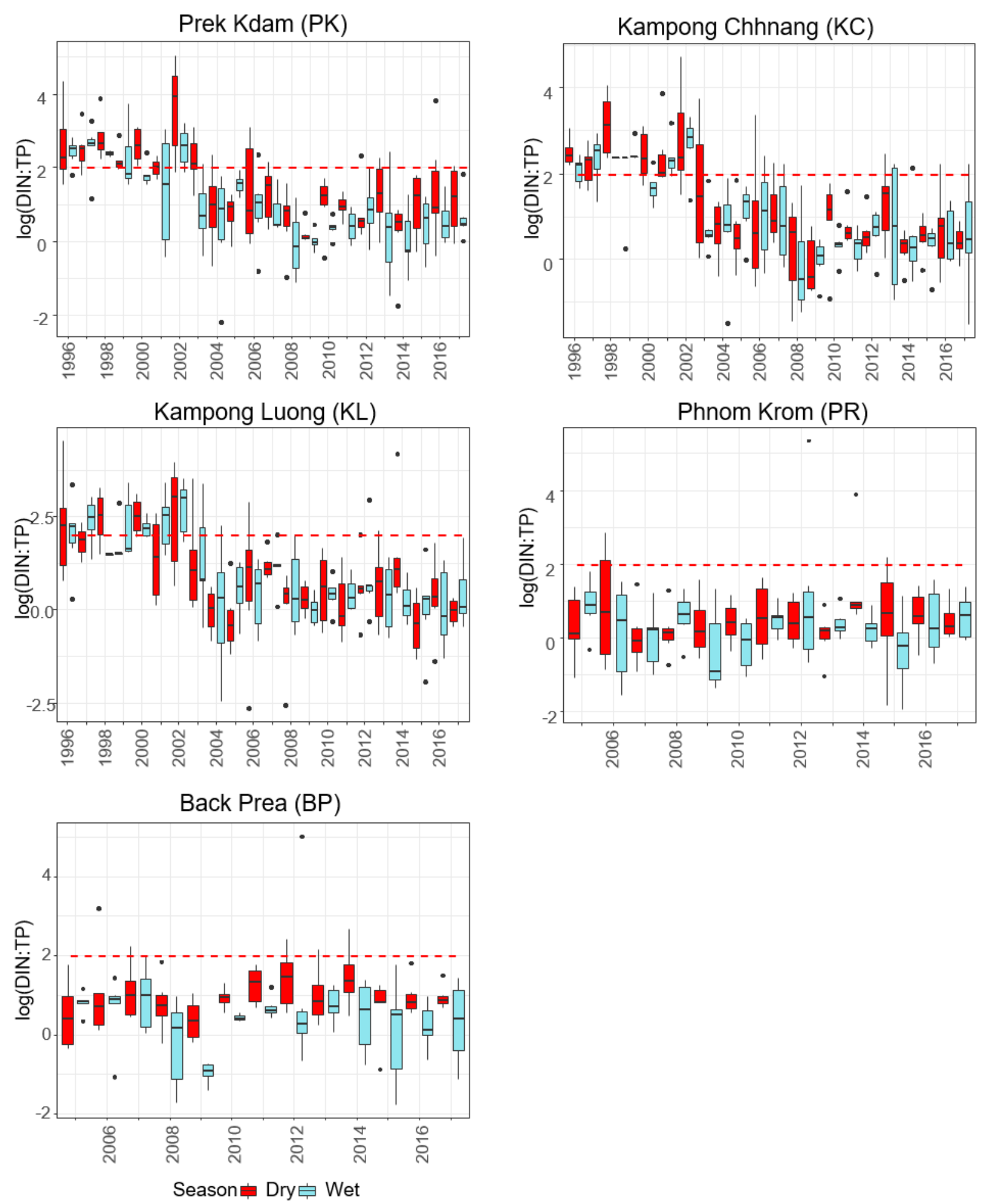

Figure 3. Temporal variation of the DIN:TP by weighted mass ratio, and grouped by wet and dry seasons. The red dashed line indicates the ratio equal to 7.2 which is the potentially optimized, nitrogen to phosphorus ratio as determined by Redfield during study periods needed for phytoplankton growth. 

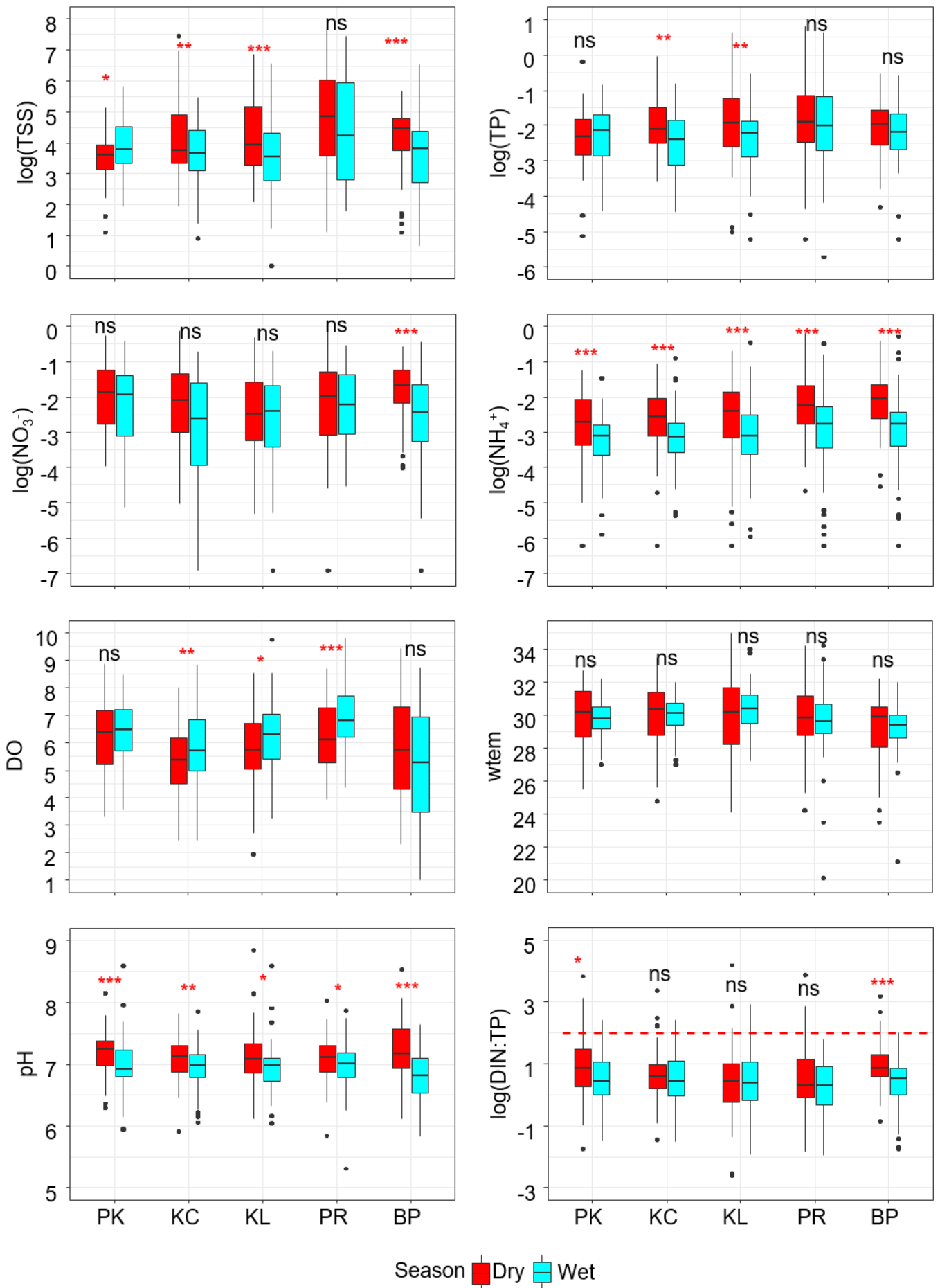

Figure 4. Wet versus dry season of water quality parameters by site in the Tonle Sap Ecosystem from 2005 to 2017 . The significance levels are labeled as "ns" for a $p$-value $>0.05,{ }^{*} p$-value $\leq 0.05,{ }^{* *} p$-value $\leq 0.01$, and ${ }^{* *} p$-value $\leq 0.001$. The red dashed line indicates the ratio of DIN:TP at 7.2 by mass weight.

\subsection{Drivers of Water Quality Change}

The relationship between the study water quality parameters and environmental drivers (e.g., max water levels, climate, and land use types) and human population density for each site is presented in Table 3. 
Table 3. Multiple linear regression coefficients between the eight water quality parameters and independent variables by site in the Tonle Sap Ecosystem.

\begin{tabular}{|c|c|c|c|c|c|c|}
\hline \multirow{2}{*}{ Parameters } & \multirow{2}{*}{ Predictors } & \multicolumn{5}{|c|}{ Sites } \\
\hline & & PK & KC & KL & BP & PR \\
\hline \multirow{10}{*}{ TSS } & Max. WL & $3.42 * *$ & 1.89. & $2.55 *$ & $3.02 *$ & $(-) 1.14$ \\
\hline & Air Temperature & 2.11. & $2.34 *$ & $2.36 *$ & - & $(-) 0.93$ \\
\hline & Precipitation & $(-) 1.47$ & - & - & $(-) 2.94 *$ & $(-) 1.02$ \\
\hline & Forest cover & $(-) 1.90$ & -1.92 & $(-) 2.87 *$ & $(-) 5.87 * *$ & 1.32 \\
\hline & Flooded forest & - & - & - & 1.87 & - \\
\hline & Population density & $(-) 1.67$ & $(-) 1.17$ & $-2.61 *$ & - & 1.73 \\
\hline & Plantation & - & $(-) 2.30 *$ & - & 1.76 & 0.95 \\
\hline & Crops & - & $(-) 2.34$ * & - & $(-) 3.45 *$ & $(-) 2.44$. \\
\hline & Rice & - & - & $(-) 1.86$ & - & - \\
\hline & Multiple $\mathrm{R}^{2}$ & 0.53 & 0.59 & 0.65 & 0.93 & 0.68 \\
\hline \multirow{10}{*}{ TP } & Max. WL & - & - & - & - & -1.56 \\
\hline & Air Temperature & $(-) 1.49$ & - & - & - & - \\
\hline & Precipitation & - & - & - & - & - \\
\hline & Forest cover & $(-) 2.54 *$ & $(-) 3.39 * *$ & $(-) 3.94^{* *}$ & - & - \\
\hline & Flooded forest & $(-) 3.83^{* *}$ & $(-) 2.12$ & $(-) 1.59$ & - & - \\
\hline & Population density & $(-) 3.70 * *$ & $(-) 6.13 * * *$ & $(-) 5.43^{* * *}$ & - & - \\
\hline & Plantation & - & $(-) 1.74$ & - & & - \\
\hline & Crops & - & - & - & 1.48 & - \\
\hline & Rice & - & - & - & - & $2.73 *$ \\
\hline & Multiple $\mathrm{R}^{2}$ & 0.78 & 0.87 & 0.83 & 0.17 & 0.43 \\
\hline \multirow{10}{*}{$\mathrm{NO}_{3}{ }^{-}$} & Max. WL & - & - & - & $(-) 2.79 *$ & $(-) 4.68^{* *}$ \\
\hline & Air Temperature & - & - & - & $(-) 1.46$ & $(-) 3.03 *$ \\
\hline & Precipitation & - & - & - & 1.94 & - \\
\hline & Forest cover & $(-) 1.37$ & - & - & 1.9 & $3.32 *$ \\
\hline & Flooded forest & - & - & - & - & $(-) 3.26$ * \\
\hline & Population density & $(-) 1.53$ & - & - & 1.73 & $2.73 *$ \\
\hline & Plantation & - & - & - & 2.31 & - \\
\hline & Crops & - & - & - & - & $(-) 4.79 * *$ \\
\hline & Rice & - & - & - & 0.95 & - \\
\hline & Multiple $\mathrm{R}^{2}$ & 0.27 & - & - & 0.71 & 0.91 \\
\hline \multirow{10}{*}{$\mathrm{NH}_{4}{ }^{+}$} & Max. WL & $3.06^{* *}$ & - & $(-) 2.37 *$ & $(-) 1.07$ & $(-) 1.64$ \\
\hline & Air Temperature & - & - & $(-) 4.69 * * *$ & - & $(-) 1.1$ \\
\hline & Precipitation & - & 1.7 & - & 1.5 & $5.51 * *$ \\
\hline & Forest cover & - & $(-) 1.87$ & - & - & $(-) 1.76$ \\
\hline & Flooded forest & $(-) 2.91 *$ & - & - & 1.95 & 1.88 \\
\hline & Population density & $(-) 2.03$ & -1.65 & - & 1.67 & - \\
\hline & Plantation & - & - & - & $2.66 *$ & $4.03 *$ \\
\hline & Crops & - & - & - & 2.26 & 1.61 \\
\hline & Rice & - & - & - & $2.58 *$ & $5.46^{* *}$ \\
\hline & Multiple $\mathrm{R}^{2}$ & 0.67 & 0.39 & 0.54 & 0.82 & 0.96 \\
\hline \multirow{10}{*}{ DIN:TP } & Max. WL & - & - & - & 1.54 & 2.41 \\
\hline & Air Temperature & 1.83. & - & - & - & 1.89 \\
\hline & Precipitation & - & - & - & - & - \\
\hline & Forest cover & 1.51 & $2.87 *$ & $4.19^{* *}$ & $(-) 1.57$ & $(-) 1.49$ \\
\hline & Flooded forest & $3.38^{* *}$ & - & - & $2.48 *$ & - \\
\hline & Population density & $2.71 *$ & $2.25 *$ & $3.08^{* *}$ & $(-) 1.54$ & $(-) 1.89$ \\
\hline & Plantation & - & - & 2.00 & $3.30 *$ & - \\
\hline & Crops & - & - & $2.21 *$ & $2.70 *$ & 1.97. \\
\hline & Rice & - & $(-) 1.94$. & $(-) 1.47$ & - & $(-) 2.31$ \\
\hline & Multiple $\mathrm{R}^{2}$ & 0.70 & 0.77 & 0.81 & 0.76 & 0.71 \\
\hline \multirow{10}{*}{ DO } & Max. WL & - & - & $(-) 1.25$ & $(-) 2.70 *$ & $(-) 2.02$ \\
\hline & Air Temperature & - & - & - & $(-) 4.11 * *$ & $(-) 1.75$ \\
\hline & Precipitation & $(-) 2.08$. & - & - & $(-) 2.43$ & - \\
\hline & Forest cover & - & - & $2.87 *$ & 1.67 & $2.77^{*}$ \\
\hline & Flooded forest & $(-) 2.26 *$ & - & $(-) 2.79 *$ & $5.35^{* *}$ & - \\
\hline & Population density & $(-) 1.85$ & - & - & $4.78^{* *}$ & $2.83 *$ \\
\hline & Plantation & -1.4 & - & $(-) 2.11$. & $6.09 * *$ & - \\
\hline & Crops & - & 1.57 & - & - & - \\
\hline & Rice & $(-) 1.90$ & $(-) 1.66$ & $(-) 5.22 * * *$ & - & - \\
\hline & Multiple $\mathrm{R}^{2}$ & 0.73 & 0.32 & 0.71 & 0.97 & 0.52 \\
\hline
\end{tabular}


Table 3. Cont.

\begin{tabular}{|c|c|c|c|c|c|c|}
\hline \multirow{2}{*}{ Parameters } & \multirow{2}{*}{ Predictors } & \multicolumn{5}{|c|}{ Sites } \\
\hline & & PK & KC & KL & BP & PR \\
\hline \multirow{10}{*}{$\mathrm{pH}$} & Max. WL & 2.04 . & 1.71 & - & 1.27 & 1.78 \\
\hline & Air Temperature & - & - & - & 1.24 & 0.75 \\
\hline & Precipitation & $(-) 1.43$ & $(-) 1.86$. & $(-) 2.23$ * & - & $(-) 1.3$ \\
\hline & Forest cover & $(-) 2.70$ * & - & $4.00 * *$ & - & $(-) 1.54$ \\
\hline & Flooded forest & 1.92. & 1.87. & - & $(-) 1.65$ & 1.1 \\
\hline & $\begin{array}{c}\text { Population } \\
\text { density }\end{array}$ & - & $2.25 *$ & $4.25^{* * *}$ & $(-) 1.11$ & $(-) 1.21$ \\
\hline & Plantation & - & - & - & $(-) 1.99$ & $(-) 3.43$ * \\
\hline & Crops & - & - & - & $(-) 1.15$ & 1.93 \\
\hline & Rice & - & - & - & $(-) 1.05$ & -1.3 \\
\hline & Multiple $\mathrm{R}^{2}$ & 0.56 & 0.44 & 0.62 & 0.76 & 0.92 \\
\hline \multirow{10}{*}{ wtem } & Max. WL & - & - & $(-) 2.59$ * & $(-) 2.07$. & 1.14 \\
\hline & Air Temperature & $2.73 *$ & - & - & - & - \\
\hline & Precipitation & - & - & - & 0.98 & $2.94 *$ \\
\hline & Forest cover & - & - & $2.66 *$ & - & $(-) 1.89$ \\
\hline & Flooded forest & 1.51 & $3.24 * *$ & $(-) 1.27$ & 1.84 & 1.76 \\
\hline & $\begin{array}{c}\text { Population } \\
\text { density }\end{array}$ & 1.81. & $3.68^{* *}$ & 1.59 & 1.14 & $(-) 1.3$ \\
\hline & Plantation & - & - & $(-) 2.48$ * & 1.31 & $(-) 2.42$. \\
\hline & Crops & - & - & - & 1.88 & $3.29 *$ \\
\hline & Rice & - & - & $(-) 1.36$ & 1.5 & $(-) 1.39$ \\
\hline & Multiple $\mathrm{R}^{2}$ & 0.59 & 0.62 & 0.71 & 0.71 & 0.93 \\
\hline
\end{tabular}

The model performance for the parameters is indicated as the multiple $\mathrm{R}^{2}$. A dash " -"indicates no relationship between parameters and predictors. The minus sign " $(-)^{\prime \prime}$ indicates a negative relationship. Significance levels are: ${ }^{*} p$-value $\leq 0.05,{ }^{* *} p$-value $\leq 0.01$, and ${ }^{* * *} p$-value $\leq 0.001$.

For TSS, the coefficient of determination $\left(R^{2}\right)$ of the model for each site explains between 50 to $70 \%$ of the total variance, while the model $\mathrm{R}^{2}$ explained up to $93 \%$ in BP. Max. WL had a significantly positive relationship with TSS from the south to north across the lake (PK, KL, and BP), while the opposite was found for land cover types (e.g., forest cover and crops) over the study period. For TP, the model $\mathrm{R}^{2}$ explained about $80 \%$ for sites in the southern and middle part of the lake (PK, KC, and $\mathrm{KL}$ ). Land use change and population density were observed to have a significantly negative relationships with $\mathrm{TP}$. Toward the northern site (PR), a significantly positive relationship was indicated between TP and rice farming, with $\mathrm{R}^{2}$ of 0.43 .

$\mathrm{NO}_{3}{ }^{-}$was negatively related with most of the predictors in the northern sites of the lake except for precipitation, plantation and rice farming in $P R\left(R^{2}=0.91\right)$ while, in $B P$, Max. WL significantly explained the change in $\mathrm{NO}_{3}{ }^{-}\left(\mathrm{R}^{2}=0.71\right)$.

$\mathrm{NH}_{4}{ }^{+}$was negatively correlated with Max. WL and air temperature in the open area of the lake in $\mathrm{KL}\left(\mathrm{R}^{2}=0.54, p<0.05\right)$. At the river site $(\mathrm{PK}), \mathrm{NH}_{4}{ }^{+}$was positively correlated with Max. WL and negatively correlated with flooded forest $\left(\mathrm{R}^{2}=0.67, p<0.05\right)$. $\mathrm{NH}_{4}{ }^{+}$ was significantly correlated to precipitation, plantation, and rice farming with $R^{2}$ of 0.96 and $0.82(p<0.05)$ for PR and BP, respectively.

The DIN:TP ratio had a significantly positive relationship with human population density and the change in watershed land use $\left(\mathrm{R}^{2}\right.$ range from 0.70 to $\left.0.81, p<0.05\right)$ across the system except PR.

DO was negatively correlated with flooded forest in PK $\left(R^{2}=0.73, p<0.05\right)$, and with flooded forest and rice farming in $\mathrm{KL}\left(\mathrm{R}^{2}=0.71, p<0.05\right)$. In the northern sites, we found a significant positive relationship between $\mathrm{DO}$ and population density as well as forest cover, but a negative relationship with Max. WL, with an $\mathrm{R}^{2}$ of 0.52 and 0.97 for PR and BP, respectively. 
$\mathrm{pH}$ exhibited a significant negative relationship with forest cover in $\mathrm{PK}\left(\mathrm{R}^{2}=0.56\right)$ but a positive relationship to population density in $K C\left(R^{2}=0.44\right)$. In the open area of the lake $(\mathrm{KL}), \mathrm{pH}$ was negatively related to precipitation and positively correlated to forest cover and population density $\left(\mathrm{R}^{2}=0.62, p<0.05\right)$. In the north of the lake, $\mathrm{pH}$ was negatively correlated to plantation in PR $\left(\mathrm{R}^{2}=0.92, p<0.05\right)$.

Water temperature was positively correlated with air temperature in $P K\left(R^{2}=0.59\right)$, and with flooded forest and population density in $K C\left(R^{2}=0.62\right)$. In the open area of lake $(\mathrm{KL})$, wtem had a positive relationship with forest cover but a negative relationship with Max. WL and plantations $\left(\mathrm{R}^{2}=0.71, p<0.05\right)$. In the north (PR), wtem was positively correlated to precipitation and crops $\left(R^{2}=0.93, p<0.05\right)$, while no significant relationship between wtem and all predictive variables was found in BP.

The relationship between water quality parameters and predictors for dry and wet season is summarized in Supplementary Materials Tables S3 and S4. We found both dissimilar and similar drivers of change in water quality between seasons and this may be related to local conditions of each site. For example, precipitation impacted TSS in BP during the wet season but not in the dry season while TSS in PR was related to crops in both the wet and dry seasons.

\section{Discussion}

\subsection{Spatial Heterogeneity of Water Quality in the Tonle Sap Lake-River Ecosystem}

There was significant variability in space and time of water quality parameters within the TSE which affects the lake ecosystem. Higher concentration of TSS, TP, and $\mathrm{NH}_{4}{ }^{+}$in the northern part of TSL may be caused from water level changes, altered sediment transport from TSL and Mekong River's tributaries [11,29], and chemical pollution from rice fields [5]. Changes in land management such as forest cover, flooded forest, and human waste likely drives the localized response of TP in the southern part of the lake. Changes in watershed and urban TP loading has also occurred in Lake Victoria, another large, tropical freshwater ecosystem [56].

Water temperature governs metabolism, biogeochemical transformations, and the distribution of biodiversity [57]. Lower water temperature in the northern part of TSL compared to southern locations may be related to agricultural development and floodplain deforestation [27]. The southern sites are within shallow and open water and connections to the atmosphere, compared to the north part e.g., $\mathrm{BP}$ which is covered by trees along the tributary inputs, connecting to mountains such as the Kulen mountain in Siem Reap and Cardamon mountain in Pursat.

DO is spatially variable within the TSE. Other authors have also noted spatially variable patterns in DO across TSL [58]. Quantifying why spatial variability occurs is complex but could be associated with lake depth and resulting physical air-water turbulence, biogeochemical oxygen demand within benthic sediments, or algal production. Moreover, the greening of the Mekong River, meaning increased algal production of the Mekong River, has been identified as a potential driver and has occurred from drought and changing in the Mekong's hydrology. This greening is likely due to the increases in algal production which would result in spatial variability of DO. The lowest median of DO was $5.5 \pm 0.17 \mathrm{mg} / \mathrm{L}$ at BP. Thus, in general, DO concentrations were adequate for aquatic life [30] and not likely a concern for the lake as whole.

The $\mathrm{pH}$ values and $\mathrm{NO}_{3}{ }^{-}$concentrations were similar across study sites of the TSE. This result is likely due to chemical constituents and buffering capacity of lake water, which has also occurred in the Lake Victoria [59]. The minimum $\mathrm{pH}$ value at each site ranged from 5.3 to 6.0 (Table S1). Literature suggests these values could be harmful to aquatic life [34]. The spatial variation of DIN:TP might be related to different spatial pattern of nutrients nitrogen and phosphorus loading and concentration within the lake, as we suggest in the description above. 


\subsection{Water Quality Trends}

The time series analysis indicated significant temporal changes to some of the water quality constituents of the TSE (Table 2). Sediment contributions are an important factor for explaining potential changes in the decline of fish catch in the Lower Mekong Basin. In some locations of the lake, increasing floodplain vegetation density also reduces soil erosion and TSS concentrations [25]. The decline in forest cover and water level [5,25] leads to spatial variability in the sediment pulse and increased TSS. Quantifying new sediments deposition from sub-watersheds surrounding the lake versus internally cycled sediment from lake mixing is an important next step for understanding TSS dynamics in the TSE. To our knowledge, very little effort has been undertaken to quantify TSS loads from the sub-watersheds entering TSL, which may become increasingly important as the mainstem Mekong River, and its tributaries are dammed [60].

Variability of TP increased in the southern part of the lake through time (Table 2). We believe this is from increasing human population and decline in flooded forest and forest cover resulting in nonpoint run-off (Table 3). Conversely, Chea et al. [2] found that TP increased in the northern part of TSL, a trend we observed in BP though it was not significant. The timescales of the studies are different. Chea et al. [2] measured dynamics from 1995 to 2010 while our study was conducted using data from 1996 to 2017. Given the changes to the Mekong River in the last decade from dam building, and altered hydrology, we may be observing more recent change in our study.

$\mathrm{NO}_{3}{ }^{-}$declined over time in the southern extent (PK and $\mathrm{KC}$ ), while increasing trends were observed in $\mathrm{BP}$, possibly from land use changes and dam development in the Lower Mekong River that reduced water flow [60-62]. While a previous study found $\mathrm{NH}_{4}{ }^{+}$ increase in north of TSL [2], we found $\mathrm{NH}_{4}{ }^{+}$increased in PK and $\mathrm{KC}$, which may be attributed to flooded forest loss or biogeochemical changes in the sediment-water interface of this shallow lake ecosystem. Mechanistic studies which evaluate nutrient transformation (denitrification and nitrification) along the river gradient are necessary to understand the control of nitrogen species in the Mekong River.

Temporal $\mathrm{pH}$ increased particularly over the last decade could be sediment presented in the water increased nutrients and alkalinity in water. Overall, water temperature is warming slightly through time. Daly et al. [27] also found a monthly temperature increase $0.03{ }^{\circ} \mathrm{C}$ per year between 1988 to 2018 during the dry season in TSL due to warming air temperatures. Increasing water temperature could lead to future stress to fish, affecting biodiversity, especially for non-migratory fishes [57]. For example, lower fish species richness and yield were observed in the north part of the lake [63]. Warm water increases in the north part of the TSE might be related to pollution since water temperature, nutrients, and TSS increase in tandem, as described above.

DO trends were variable depending on sediment flux, air temperature, forest cover, and flooded forest $[25,27,43]$. Chea et al. [2] found a decline in DO in the northern part of the lake due to human activities. We also observed declining DO in PR from 2006 to 2010. This decline may be attributed to the site location near Siem Reap city, a tourist destination city with expected more pollution anticipated than at other sites. On the contrary, DO was increasing at BP, a site with substantial forest cover. Given recent hydroclimate changes of the Lower Mekong River, understanding water temperature trends could be a key to understanding changes to the TSE. Yang et al. [64] have demonstrated that increasing water temperatures and TP were the factors driving increasing phytoplankton abundance in Fenhe River, China.

\subsection{Seasonal Pattern in Water Quality}

In the TSE, we found that water quality parameters often differed between seasons (Figure 4). Higher sediment influxes occurred at TSL during the dry season when the lake becomes shallow and agricultural activities increase around the perimeter of the lake [23]. Sediment is also delivered to the lake through tributary inputs. At the same time, sediment at the bottom of the lake is resuspended due to wind movement and increased chemical 
concentration i.e., TSS, $\mathrm{TP}, \mathrm{NH}_{4}{ }^{+}$, and $\mathrm{NO}_{3}{ }^{-}[5,25,65]$. However, at PK in the TSR, sediment during the wet season was about $20 \%$ higher than the dry season [66]. Lake pH differed between seasons and was significantly correlated with TSS and nutrients (Table S2). DO was influenced by floodplain changes [5]. However, a negative correlation between TSS and DO (Table S2) suggested that DO was reduced by TSS in KC, KL, and PR during the dry season perhaps from reduced primary production [67]. Utilizing other techniques to assess the amount of algal biomass, through chlorophyll-a pigmentation or oxygen water quality sensors, and free water metabolism measurements could assist in understanding links between TSS and algal productivity over time. Our results contrasted with Chea et al. [2] because we found a strong seasonal influence on most water quality parameters in the TSE. This could be due to the differences in study period length (see Section 4.2), climate, and development around the system in the last decade. We found similar results to [58] showing that water temperature across the system does not significantly differ between seasons.

\subsection{Potential Nutrient Limitation Change to Algal Production}

Even with the extensive spatial variation in water quality parameters presented above (Figure 2), the TSE may be a N-limited ecosystem similar to much of the Lower Mekong River system [68] and other tropical lake systems [68]. N limitation in the TSE was also confirmed by Campbell [5] based on mean monthly N:P ratio of 7.0. On the contrary, Bennet et al. [69] suggested the lake productivity is limited by phosphorus. Our studies interpreted used different water source (ground water versus surface waters), thresholds, and chemical constituents for interpreting nutrient limitation. For example, Burnett et al. [69] used the atomic ratio of DIN:DIP > 22 for P-limitation and DIN:DIP $<10$ for N-limitation while our study used threshold of the Redfield ratio by mass of 7.2, where measurement below 7.2 are N-limited [70]. Future efforts should incorporate measurements of DIP, conduct P release experiments (as conducted in Bennet et al.), and employ nutrient bioassays experiments across TSL gradient to quantify algal limitation.

The significant difference of DIN:TP between wet and dry season revealed that there were seasonal dynamics influencing productivity in PK and BP. Under nitrogen limitation, high algae growth [70,71] and cyanobacteria blooms (blue-green algae) could occur [67,72]. Likewise, Campbell et al. [73] found green algae and cyanobacteria dominated with phytoplankton from August 2003 to May 2004 in the TSE.

\subsection{Influence of Water Parameters}

The multiple linear regression indicated that water level drives sediment concentrations, $\mathrm{NO}_{3}{ }^{-}$, and $\mathrm{NH}_{4}{ }^{+}$in TSE. Population density, vegetation, flooded forest, and forest cover, and climate (air temperature and rainfall) also govern changes in water quality parameters [23,27]. This could influence distribution and migrations of fish species in TSL [74]. Moreover, rice field activities decreased in PR in the last decade due to urbanization and that might have reduced chemical fertilizer and pesticide use [75]. A recent study found a $26.3 \%$ reduction of resuspended sediment by floodplain vegetation and that flood pulse changes affected sediment fluxes between wet and dry seasons [76].Forest cover may interact with TP in the southern part of the lake and with TSS in KL.

\section{Conclusions}

There are few, if any studies of long-term dynamics from tropical lakes particular those which play a major role in the production of the world's freshwater biodiversity. There are also few studies that integrate rivers and lakes to understand nutrient, temperature, and pollution effects on fish production [77]. In this study, we found that long-term water quality parameters in the TSE change in space and time depending on watershed land use, water level dynamics, population density, air temperature, precipitation, and flood pulse change. TSS in river sites was influenced by water level and is probably related to inflow from the Mekong River. TSS in lake sites was affected by runoff, rising air temperature, 
and resuspended sediment from the bottom of the lake. TP has increased in the TSE due to the loss of forest cover and flooded forest, and rising population density. Similarly, rice production likely contributed TP to the TSE. Changes in water level, flooded forest, forest losses, crops, plantation, population density, and climate have changed in $\mathrm{NH}_{4}{ }^{+}$and $\mathrm{NO}_{3}{ }^{-}$in water, particularly in the north part of the lake. $\mathrm{DO}$, water temperature and $\mathrm{pH}$ in $\mathrm{KL}$ and the northern part of the lake were are threatened by low water levels, change in forest and flooded forest cover, population, and climate. At the same time, variability of $\mathrm{DO}, \mathrm{pH}$, and water temperature in TSR (PR) and $\mathrm{KC}$ occurred due to deforestation and air temperature change. Lastly, DIN:TP ratio change in space and time, indicating potential alterations to algal nutrient limitation which should be further studied if we are to understand the linkages between changes in hydrology and changes to fish production.

Our research highlights the need for research examine links between the spatialtemporal patterns of water quality and fish production and biodiversity. For example, Chea et al. [2] showed that spatial patterns of DO, $\mathrm{pH}$, and TP influenced the spatial structure of the fish assemblages in the Lower Mekong River. It is likely that variations in water quality in the TSE drive some of the spatial and temporal variation of fish catch, similarly to what has been found in [78] and in the Amazon River [79]. We recommend spatially distributed water concentration monitoring in the same locations of fisheries monitoring to answer these questions and predict future fish diversity and yield scenarios. We also recommend investigating the species specific water quality tolerances of fishes, and another biodiversity to each water constituents. Researchers are needed to support research that considers mechanistic investigations to understand the biogeochemical and metabolism transformations associated with elevated temperatures, changes in nutrient state, and light. In general, there are far fewer studies in the literature related to the mechanistic understanding of basic limnological processes including metabolism and nutrient transformations in tropical aquatic ecosystems. With the flood pulse of the Mekong River and alterations to upstream hydrology, there is a unique opportunity to understand mechanistic influences of anthropogenic drivers to a tropical lake. Finally, increasing pollution of concern not only for the animal biodiversity but also for human health. Local people who use water directly from the lake or river system. In summary, the Cambodian government and scientists should invest in understanding water quality drivers and their implication for food web production in the system to improve biodiversity, and human health for the impoverished that depend on the Tonle Sap ecosystem functions and services.

Supplementary Materials: The following are available online at https:/ / www.mdpi.com/article/ 10.3390/w13152059/s1, Table S1. Summary data. Table S2. Decomposition time series. Table S3. Correlation matrix. Table S4. Plots of drivers. Table S5. Drivers of water quality change in wet and dry season.

Author Contributions: Conceptualization, S.S., S.C. and P.B.N.; Data curation, S.S., P.B.N. and S.C.; Formal analysis, S.S., P.B.N. and S.C.; Funding acquisition, Z.S.H. and S.C.; Investigation, S.S. and P.B.N.; Methodology, S.S., S.C. and P.B.N.; Project administration, Z.S.H., S.C. and P.B.N.; Supervision, S.C., P.B.N. and Z.S.H.; Validation, S.C., P.B.N. and Z.S.H.; Visualization, S.S., P.B.N., B.C. and S.C.; Writing—original draft, S.S.; Review \& editing, S.S., S.C., P.B.N., Z.S.H., S.E.N., T.E.D., S.L., S.K., F.T. and B.C. All authors have read and agreed to the published version of the manuscript.

Funding: Funding provided by the USAID supported "Wonders of the Mekong" Cooperative Agreement No: AID-OAA-A-16-00057 to Z. Hogan, S. Chandra and others.

Data Availability Statement: The data presented in this study are available in raw form via request to the Mekong River Commission or P.B.N by writing.

Acknowledgments: We are grateful to the Inland Fisheries Research and Development Institute (IFReDI) of the Cambodia Fisheries Administration for the support to the study and the Mekong River Commission for providing datasets used in this study.

Conflicts of Interest: The authors declare no conflict of interest. 


\section{References}

1. Alabaster, J.S. Water Quality Criteria for Freshwater Fish, 2nd ed.; Food and Agriculture Organization of the United Nations (FAO): Rome, Italy, 1982; Volume 24, ISBN 0408108495.

2. Chea, R.; Grenouillet, G.; Lek, S. Evidence of Water Quality Degradation in Lower Mekong Basin Revealed by Self-Organizing Map. PLoS ONE 2016, 11. [CrossRef]

3. Kua, Z.X.; Hamilton, I.M.; McLaughlin, A.L.; Brodnik, R.M.; Keitzer, S.C.; Gilliland, J.; Hoskins, E.A.; Ludsin, S.A. Water warming increases aggression in a tropical fish. Sci. Rep. 2020, 10, 1-13. [CrossRef]

4. Ngor, P.B.; Legendre, P.; Oberdorff, T.; Lek, S. Flow alterations by dams shaped fish assemblage dynamics in the complex Mekong-3S river system. Ecol. Indic. 2018, 88, 103-114. [CrossRef]

5. Campbell, I.C. The Mekong: Biophysical Environment of an International River Basin, 3rd ed.; Thorp, J.H., Ed.; Academic Press: New York, NY, USA, 2009; ISBN 978-0-12-374026-7.

6. Ozaki, H.; Co, T.K.; Le, A.K.; Pham, V.N.; Nguyen, V.B.; Tarao, M.; Nguyen, H.C.; Le, V.D.; Nguyen, H.T.; Sagehashi, M.; et al. Human factors and tidal influences on water quality of an urban river in Can Tho, a major city of the Mekong Delta, Vietnam. Environ. Monit. Assess. 2014, 186, 845-858. [CrossRef] [PubMed]

7. Campbell, I.C. Perceptions, data, and river management: Lessons from the Mekong River. Water Resour. Res. 2007, 43, 1-13. [CrossRef]

8. Ngor, P.B.; Grenouillet, G.; Phem, S.; So, N.; Lek, S. Spatial and temporal variation in fish community structure and diversity in the largest tropical flood-pulse system of South-East Asia. Ecol. Freshw. Fish 2018, 27, 1087-1100. [CrossRef]

9. Campbell, I.C.; Say, S.; Beardall, J. Tonle Sap Lake, the Heart of the Lower Mekong. In The Mekong: Biophysical Environment of an International River Basin; Academic Press publications: Cambridge, MA, USA, 2009; pp. 251-272. ISBN 9780123740267.

10. Lamberts, D. The Tonle Sap Lake as a productive ecosystem. Int. J. Water Resour. Dev. 2006, 22, 481-495. [CrossRef]

11. Kummu, M.; Koponen, J.; Sarkkula, J. Modelling Sediment and Ecosystem in Tonle Sap Lake for Impact Assessment. RMZ-Mater. Geoenviron. 2005, 52, 87-89.

12. Poulsen, A.F.; Poeu, O.; Viravong, S.; Suntornratana, U.; Tung, N.T. Fish Migrations of the Lower Mekong River Basin: Implications for Development, Planning and Environmental Management; Bishop, A., Ed.; Mekong River Commission: Phnom Penh, Cambodia, 2002.

13. Bishop, A.; Veasna, B.; Campbell, I.; Feldkotter, C.; Garsdal, G.S.; Gerrinck, L.; Griffiths, D.; Hodgkinson, P.; Hook, J.; Ishihata, T.; et al. State of the Basin Report: 2003 Executive Summary; Mekong River Commission: Phnom Penh, Cambodia, 2003.

14. Hortle, K.G.; Bamrungrach, P. Fisheries Habitat and Yield in the Lower Mekong Basin; Starr, P., Ngor, P.., Degen, P., So, N., Eds.; Mekong River Commission: Phnom Penh, Cambodia, 2015.

15. Hortle, K.G. Consumption and the Yield of Fish and Other Aquatic Animals from the Lower Mekong Basin; Burnhil, T.J., Ed.; Mekong River Commission: Vientiane, Laos, 2017.

16. Johnstone, G.; Ranjitha, P.; Fabrice, D.; Kosal, M.; Oeur, I.; Sithirith, M.; Bunna, P.; Sophat, S.; Sokheng, C.; Sochanny, H.; et al. Tonle Sap Scoping Report; CGIAR Research Program on Aquatic Agricultural Systems: Penang, Malaysia, 2013.

17. Sor, R.; Ngor, P.B.; Soum, S.; Chandra, S.; Hogan, Z.S.; Null, S.E. Water quality degradation in the lower mekong basin. Water 2021, 13, 1555. [CrossRef]

18. Arias, M.E.; Cochrane, T.A.; Piman, T.; Kummu, M.; Caruso, B.S.; Killeen, T.J. Quantifying changes in flooding and habitats in the Tonle Sap Lake (Cambodia) caused by water infrastructure development and climate change in the Mekong Basin. J. Environ. Manag. 2012, 112, 53-66. [CrossRef]

19. Arias, M.E.; Holtgrieve, G.W.; Ngor, P.B.; Dang, T.D.; Piman, T. Maintaining perspective of ongoing environmental change in the Mekong floodplains. Environ. Sustain. 2019, 37, 1-7. [CrossRef]

20. Sabo, J.L.; Ruhi, A.; Holtgrieve, G.W.; Elliott, V.; Arias, M.E.; Ngor, P.B.; Räsänen, T.A.; Nam, S. Designing river flows to improve food security futures in the Lower Mekong Basin. Science (80-) 2017, 358. [CrossRef] [PubMed]

21. Oeurng, C.; Cochrane, T.A.; Chung, S.; Kondolf, M.G.; Piman, T.; Arias, M.E. Assessing climate change impacts on river flows in the Tonle Sap Lake Basin, Cambodia. Water 2019, 11, 618. [CrossRef]

22. Arias, M.E.; Piman, T.; Lauri, H.; Cochrane, T.A.; Kummu, M. Dams on Mekong tributaries as significant contributors of hydrological alterations to the Tonle Sap Floodplain in Cambodia. Hydrol. Earth Syst. Sci. 2014, 18, 5303-5315. [CrossRef]

23. Kummu, M.; Sarkkula, J. Impact of the Mekong River flow alteration on the Tonle Sap flood pulse. AMBIO A J. Hum. Environ. 2008, 37, 185-192. [CrossRef]

24. Lu, X.; Kummu, M.; Oeurng, C. Reappraisal of sediment dynamics in the Lower Mekong River, Cambodia. Earth Surf. Process. Landforms 2014, 39, 1855-1865. [CrossRef]

25. Hoshikawa, K.; Fujihara, Y.; Siev, S.; Arai, S.; Nakamura, T.; Fujii, H.; Sok, T.; Yoshimura, C. Characterization of total suspended solid dynamics in a large shallow lake using long-term daily satellite images. Hydrol. Process. 2019, 33, 2745-2758. [CrossRef]

26. Lohani, S.; Dilts, T.E.; Weisberg, P.J.; Null, S.E.; Hogan, Z.S. Rapidly accelerating deforestation in Cambodia's Mekong River basin: A comparative analysis of spatial patterns and drivers. Water 2020, 12, 2191. [CrossRef]

27. Daly, K.; Ahmad, S.K.; Bonnema, M.; Beveridge, C.; Hossain, F.; Nijssen, B.; Holtgrieve, G. Recent warming of Tonle Sap Lake, Cambodia: Implications for one of the world's most productive inland fisheries. Lakes Reserv. 2020. [CrossRef]

28. Nhim, S. Station Profiles of Water Quality Monitoring Network in Cambodia, Consultancy report; Water Quality Monitoring Specialist: Phnom Penh, Cambodia, 2003. 
29. Kummu, M.; Tes, S.; Yin, S.; Adamson, P.; Józsa, J.; Koponen, J.; Richey, J.; Sarkkula, J.; Richey, J.; Sarkkula, J. Water balance analysis for the Tonle Sap Lake-floodplain system. Hydrol. Process. 2014, 28, 1722-1733. [CrossRef]

30. MRC. Overview of the Hydrology of the Mekong Basin; Mekong River Commission: Vientiane, Laos, 2005.

31. MRC. 2017 Lower Mekong Regional: Water Quality Monitoring Report; Mekong River Commission: Vientiane, Laos, 2019.

32. Ly, K.; Larsen, H.; Van Duyen, N. 2013 Lower Mekong Rigional Water Quality Monitoring Report; Taylor, R., Ed.; Mekong River Commission: Vientiane, Laos, 2013.

33. Eaton, A.; Clesceri, L.; Greenberg, A.F.M. APHA Method 4500-P. Stand. Methods Exam. Water Wastewater 1992, 552, 4.108-4.117.

34. Ly, K.; Larsen, H. 2014 Lower Mekong Regional: Water Quality Monitoring Report; Brown, R., Ed.; Mekong River Commission: Vientiane, Laos, 2014.

35. Jarvis, A.; Reuter, H.; Nelson, A.D.; Guevara, E. Hole-Filled SRTM for the Globe Version 4: Data Grid. Available online: http:/ / srtm.csi.cgiar.org/ (accessed on 19 August 2008).

36. Tarboton, D.G.; Bras, R.L.; Rodriguez-Iturbe, I. On the extraction of channel networks from digital elevation data. Hydrol. Process. 1991, 5, 81-100. [CrossRef]

37. Regional Land Cover Monitoring System Version 2. Available online: https://www.landcovermapping.org/en/landcover/ (accessed on 11 April 2020).

38. Doxsey-Whitfield, E.; MacManus, K.; Adamo, S.B.; Pistolesi, L.; Squires, J.; Borkovska, O.; Baptista, S.R. Taking Advantage of the Improved Availability of Census Data: A First Look at the Gridded Population of the World, Version 4. Pap. Appl. Geogr. 2015, 1, 226-234. [CrossRef]

39. Harris, I.C.; Jones, P.D. CRU TS4.03: Climatic Research Unit (CRU) Time-Series (TS) version 4.03 of high-resolution gridded data of month-by-month variation in climate (January 1901-December 2018). Available online: http:/ / dx.doi.org/10.5285/10d3e364 0f004c578403419aac167d82 (accessed on 22 January 2020).

40. Pierce, D. Ncdf4: Interface to Unidata netCDF. R Packag. Version 1.17. 2019. Available online: https:/ / cran.r-project.org/web/ packages/ncdf4/index.html (accessed on 7 May 2021).

41. Hijmans, R.J. Raster: Geographic Data Analysis and Modeling. R Packag. Version 3.3-13. 2020. Available online: https: / / www.researchgate.net/publication/311921423_Raster_Raster_Geographic_data_analysis_and_modeling (accessed on 7 May 2021).

42. Rob, A.; Ihaka, R.; Reid, D.; Shaub, D. Interpolate Missing Values in a Time Series. In Forecasting Functions for Time Series and Linear Models; 2020; pp. 95-97. ISBN 0000000221405. Available online: https://cran.r-project.org/web/packages/forecast/forecast.pdf (accessed on 7 May 2021).

43. Ngor, P.B.; Oberdorff, T.; Phen, C.; Baehr, C.; Grenouillet, G.; Lek, S. Fish assemblage responses to flow seasonality and predictability in a tropical flood pulse system. Ecosphere 2018, 9, e02366. [CrossRef]

44. Wetzel, R.G. Limnology: Lake and River Ecosystem, 3rd ed.; Gulf Professional Publishing: San Diego, CA, USA, 2001; Volume 35, ISBN 9780127447605.

45. Morris, D.P.; Lewis, W.M., Jr. Phytoplankton nutrient limitation in Colorado mountain lakes. Freshw. Biol. 1988, 20, 315-327. [CrossRef]

46. Siegel, S.; Castellan, J.N.J. Non Parametric Statistics for the Behavioural Sciences, 2nd ed.; Mcgraw-Hill Book Company: New York, NY, USA, 1988.

47. Wickham, H. Ggplot2: Elegant Graphics for Data Analysis; Springer: Cham, Switzerland, 2016.

48. Cleveland, R.B.; Cleveland, W.S.; McRae, J.E.; Terpenning, I. STL: A Seasonal- Trend Decomposition Procedure Based on Loess. J. Off. Stat. 1990, 6, 3-73.

49. Eregno, F.E.; Nilsen, V.; Seidu, R.; Heistad, A. Evaluating the Trend and Extreme Values of Faecal Indicator Organisms in a Raw Water Source: A Potential Approach for Watershed Management and Optimizing Water Treatment Practice. Environ. Process. 2014, 1, 287-309. [CrossRef]

50. Hirsch, R.M.; Slack, J.R.; Smith, R.A. Techniques of trend analysis for monthly water quality data. Water Resour. Res. 1982, 18, 107-121. [CrossRef]

51. Hipel, K.W.; McLeod, A.I. Time Series Modelling of Water Resources and Environmental Systems; Elsevier Science B.V.: Amsterdam, The Netherlands, 1994; ISBN 0444892702.

52. Hirsch, R.M.; Slack, J.R. A Nonparametric Trend Test for Seasonal Data With Serial Dependence. Water Resour. Res. 1984, 20, 727-732. [CrossRef]

53. Pohlert, T. Trend: Non-Parametric Trend Tests and Change-Point Detection. R Packag. Version 1.1.4. 2020, pp. 1-18. Available online: https:/ /rdrr.io/cran/trend/ (accessed on 7 May 2021).

54. Venables, W.N.; Ripley, B.D. Modern Applied Statistics with S, 4th ed.; Springer: New York, NY, USA, $2002 ;$ ISBN 0387954570.

55. R Core Team R: A Language and Environment for Statistical Computing 2021. 2019. Available online: https://www.eea.europa. eu/data-and-maps/indicators / oxygen-consuming-substances-in-rivers/r-development-core-team-2006 (accessed on 7 May 2021).

56. Misigo, A.W.S.; Suzuki, S. Spatial-Temporal Sediment Hydrodynamics and Nutrient Loads in Nyanza Gulf, Characterizing Variation in Water Quality. World J. Eng. Technol. 2018, 6, 98-115. [CrossRef] 
57. Kraemer, B.M.; Chandra, S.; Dell, A.I.; Dix, M.; Kuusisto, E.; Livingstone, D.M.; Schladow, S.G.; Silow, E.; Sitoki, L.M.; Tamatamah, R.; et al. Global patterns in lake ecosystem responses to warming based on the temperature dependence of metabolism. Glob. Chang. Biol. 2016, 23, 1881-1890. [CrossRef] [PubMed]

58. Irvine, K.N.; Richey, J.E.; Holtgrieve, G.W.; Sarkkula, J.; Sampson, M. Spatial and temporal variability of turbidity, dissolved oxygen, conductivity, temperature, and fluorescence in the lower mekong river-tonle sap system identified using continuous monitoring. Int. J. River Basin Manag. 2011, 9, 151-168. [CrossRef]

59. Vuai, S.A.H.; Ibembe, J.D.; Mungai, N.W. Influence of Land Use Activities on Spatial and Temporal Variation of Nutrient Deposition in Mwanza Region: Implication to the Atmospheric Loading to the Lake Victoria. Atmos. Clim. Sci. 2013, 3, $224-234$. [CrossRef]

60. Null, S.E.; Farshid, A.; Goodrum, G.; Gray, C.A.; Lohani, S.; Morrisett, C.N.; Prudencio, L.; Sor, R. A meta-analysis of environmental tradeoffs of hydropower dams in the sekong, sesan, and srepok (3S) rivers of the lower mekong basin. Water 2021, 13, 63. [CrossRef]

61. Ly, K.; Metternicht, G.; Marshall, L. Linking Changes in Land Cover and Land Use of the Lower Mekong Basin to Instream Nitrate and Total Suspended Solids Variations. Sustainability 2020, 12, 2992. [CrossRef]

62. Oeurng, C.; Cochrane, T.A.; Arias, M.E.; Shrestha, B.; Piman, T. Assessment of changes in riverine nitrate in the Sesan, Srepok and Sekong tributaries of the Lower Mekong River Basin. J. Hydrol. Reg. Stud. 2016, 8, 95-111. [CrossRef]

63. Chan, B.; Ngor, P.B.; So, N.; Lek, S. Spatial and temporal changes in fish yields and fish communities in the largest tropical floodplain lake in Asia. Ann. Limnol. 2017, 53, 485-493. [CrossRef]

64. Yang, J.; Wang, F.; Lv, J.; Liu, Q.; Nan, F.; Liu, X.; Xu, L.; Xie, S.; Feng, J. Interactive effects of temperature and nutrients on the phytoplankton community in an urban river in China. Environ. Monit. Assess. 2019, 191. [CrossRef]

65. Hamilton, S.K.; Lewis, W.M., Jr. Basin morphology in relation to chemical and ecological characteristics of lakes on the Oricono River floodplain, Venezuela. Arch. Hydrobiol. 1990, 119, 393-425.

66. Kummu, M.; Penny, D.; Sarkkula, J.; Koponen, J. Sediment: Curse or blessing for Tonle Sap Lake? Ambio 2008, 37, 158-163. [CrossRef]

67. Dodds, W.K.; Whiles, M.R. Freshwater Ecology: Concepts and Environmental Applications of Limnology, 3rd ed.; Hutchins, L., Ed.; Academic Press: London, UK, 2017; ISBN 9780128132555.

68. Liljeström, I.; Kummu, M.; Varis, O. Nutrient Balance Assessment in the Mekong Basin: Nitrogen and Phosphorus Dynamics in a Catchment Scale. Int. J. Water Resour. Dev. 2012, 28, 373-391. [CrossRef]

69. Burnett, W.C.; Wattayakorn, G.; Supcharoen, R.; Sioudom, K.; Kum, V.; Chanyotha, S.; Kritsananuwat, R. Groundwater discharge and phosphorus dynamics in a flood-pulse system: Tonle Sap Lake, Cambodia. J. Hydrol. 2017, 549, 79-91. [CrossRef]

70. Downing, J.A.; Mccauley, E. The nitrogen: Phosphorus relationship in lakes. Limnol. Oceanogr. 1992, 37, 936-945. [CrossRef]

71. Van Der Molen, D.T.; Boers, P.C.M. Changes in phosphorus and nitrogen cycling following food web manipulations in a shallow Dutch lake. Freshw. Biol. 1996, 35, 189-202. [CrossRef]

72. Phlips, E.J.; Cichra, M.; Havens, K.; Hanlon, C.; Badylak, S.; Rueter, B.; Randall, M.; Hansen, P. Relationships between phytoplankton dynamics and the availability of light and nutrients in a shallow sub-tropical lake. J. Plankton Res. 1997, 19, 319-342. [CrossRef]

73. Campbell, I.C.C.; Poole, C.; Giesen, W.; Valbo-Jorgensen, J. Species diversity and ecology of Tonle Sap Great Lake, Cambodia Aquat. Sci. 2006, 68, 355-373. [CrossRef]

74. Chan, B.; Brosse, S.; Hogan, Z.S.; Ngor, P.B.; Lek, S. Influence of local habitat and climatic factors on the distribution of fish species in the tonle sap lake. Water 2020, 12, 786. [CrossRef]

75. Wang, K.; Zhang, Z.; Zhu, Y.; Wang, G.; Shi, D.; Christie, P. Surface water phosphorus dynamics in rice fields receiving fertiliser and manure phosphorus. Chemosphere 2001, 42, 209-214. [CrossRef]

76. Siev, S.; Yang, H.; Sok, T.; Uk, S.; Song, L.; Kodikara, D.; Oeurng, C.; Hul, S.; Yoshimura, C. Sediment dynamics in a large shallow lake characterized by seasonal flood pulse in Southeast Asia. Sci. Total Environ. 2018, 631-632, 597-607. [CrossRef]

77. Wurtsbaugh, W.A.; Heredia, N.A.; Laub, B.G.; Meredith, C.S.; Mohn, H.E.; Null, S.E.; Pluth, D.A.; Roper, B.B.; Carl Saunders, W.; Stevens, D.K.; et al. Approaches for studying fish production: Do river and lake researchers have different perspectives? Can. J. Fish. Aquat. Sci. 2014, 72, 149-160. [CrossRef]

78. Pin, K.; Nut, S.; Hogan, Z.S.; Chandra, S.; Saray, S.; Touch, B.; Chheng, P.; Ngor, P.B. Cambodian freshwater fish assemblage structure and distribution patterns: Using a large-scale monitoring network to understand the dynamics and management implications of species clusters in a global biodiversity hotspot. Water 2020, 12, 2506. [CrossRef]

79. Bogotá-Gregory, J.D.; Lima, F.C.T.; Correa, S.B.; Silva-Oliveira, C.; Jenkins, D.G.; Ribeiro, F.R.; Lovejoy, N.R.; Reis, R.E.; Crampton, W.G.R. Biogeochemical water type influences community composition, species richness, and biomass in megadiverse Amazonian fish assemblages. Sci. Rep. 2020, 10, 1-15. [CrossRef] 